\title{
Elektrik Kaynaklı İş Kazalarına Farklı Bir Bakış: Metal Sektöründe Yaşanan Kaza Sebeplerinin Önceliklendirilmesi
}

\author{
A Different Approach to Electricity Caused Occupational Accidents: \\ Prioritization of Accident Causes in Metal Industry
}

Ayşe Kübra HALICI , Selçuk Kürşat işLEYEN

\begin{abstract}
ÖZET
Bu çalışmada metal sektöründe yaşanan elektrik kazaları incelenmiş; kazaların sebepleri belirlenmiştir. Kaza sebeplerinin uzman kişilerce önceliklendirilmesi istenmiştir. Bu aşamada analitik hiyerarşi süreci kullanılmıştır. Çalışan hatası denilerek göz ardı edilen iş kazalarına aslında; ilk önce tasarım ve ekipman yerleşiminden kaynaklanan hataların ve daha sonra yönetimsel ve işletme temelli hataların sebep olduğu; çalışan hatasının ise en son sebep olduğu sonucuna ulaşılmıştır. Elde edilen sonuçlara göre hiyerarşik düzende kendi içinde gruplar halinde sıralamaya konan sebeplerin risk değerlendirme çalışmalarında ekip tarafından termin süresi belirlemesi esnasında rehber olması amaçlanmıştır.
\end{abstract}

Anahtar Kelimeler: Elektrik kazaları, analitik hiyerarşi süreci, iş kazası, metal sektörü.

\section{ABSTRACT}

In this study, electrical accidents in the metal sector were examined; The causes of the accidents have been revealed. It was requested to put the causes of accidents at the priority of experts. At this stage, the analytic hierarchy process is used. Work related accidents usually ignored because of employees are called accident; actually it has been achieved the causes of the accidents are firstly design and equipment placement, and later administrative and business-based mistakes. The employee error is the last cause. It is aimed that causes which are put into groups within the hierarchical level according to the outcomes are guided in the risk assessment studies during the determination of term time by the team.

Keywords: Electrical accidents, analytic hierarchy process, occupational injury, metal works.

Ayşe Kübra HALICI - Aile, Çalışma ve Sosyal Güvenlik Bakanlığı, İ̧̧ Müfettişi Yardımcısı, Ankara, Türkiye

Ayşe Kübra HALICI - Ministry of Family, Labour and Social Services, Labor Inspector, Ankara, Turkey

ORCID ID: 0000-0003-4521-1234

ayse.bostanci@ailevecalisma.gov.tr

Doç. Dr. Selçuk Kürşat işLEYEN - Gazi Üniversitesi, Mühendislik Fakültesi, Endüstri Mühendisliği Bölümü, Maltepe, Ankara, Türkiye

Assoc. Prof. Selçuk Kürşat işLEYEN, PhD - Gazi University, Faculty of Engineering, Department of Industrial Engineering, Maltepe, Ankara, Turkey ORCID ID: 0000-0002-0113-1083 


\section{GİRIŞ}

Çalışma barışının sağlanmasında iş sağlığı ve güvenliğinin etkisi çok büyüktür. Bu anlamda mevzuat ve standartların uygulanması çalışan ve işverenler arasında köprü görevi görmektedir. 6331 sayılı İş Sağlığı ve Güvenliği Kanunun 4. Maddesi işverenlerin yükümlülüklerinden, 19. Madde ise çalışanların yükümlülüklerinden bahsetmektedir. Ancak işyerinin güvenli hale getirilmesi ve güvenliğin sürdürülmesinden esas olarak işveren mesuldür [1]. Aynı kanunun 4. maddesinde işverenlerin genel yükümlülüklerinden bahsedilirken; 5 . maddede ise işverenlerin işyerlerinde bulunan risklerden nasıl korunacağından bahsedilmiştir. Çalışanlar da; işyerinde alınan önlemlere uymak ve devamlılığın sağlanmasında işverene yardımcı olmak zorundadırlar.

Ülkemizde yürürlükte bulunan iş sağlığı ve güvenliği mevzuatına rağmen her yıl binlerce çalışan iş kazası geçirmektedir. 2014 yılı Sosyal Güvenlik Kurumu (SGK) iş kazaları ve meslek hastalığı istatistiklerine bakıldığında 221.366 çalışanın iş kazası görülmektedir. 2015 yılında da 241.547 çalışan iş kazası geçirmiş bunların 45.794’i metal sektöründe meydana gelmiştir. Çalışanların 1,252'sinin geçirdiği iş kazasıı sonucu hayatını kaybettiği görülmektedir. 2016 yılında da 286.068 çalışan iş kazası geçirmiş bunların 49.506'sı metal sektöründe meydana gelmiştir. Çalışanların 1.405 'inin geçirdiği iş kazası sonucu hayatını kaybettiği görülmektedir [2].

İşyerinde kaza olan işveren yasal olarak 3 iş günü içinde SGK'ya bildirmesi gerekmektedir. Devlet bu durumun teyidini sağlayabilmek adına hastane de tedavi gören çalışanın hastane tarafından iş kazası geçirip geçirmediğinin sorgulanması ve iş kazalarını poliklinik tarihi itibariyle sigortalı bazında 10 gün içinde SGK'ya bildirilmelesini zorunlu kılmıştır. İş kazalarının istatistiksel güvenirliliği bu anlamda tarafların önemsemesine bağlı olmaktadır. İşverenin ve hastane yönetimin iş sağlığı ve güvenliği konusundaki ilgi ve tutumu; ayrıca çalışanları yaşadığı kazayı taraflara bildirmemesi gibi nedenlerle iş kazaları tam olarak belirlenememekte; sebepleri araştırılamamaktadır.

Ramak kala olaylar ya da iş gücü kaybı olmayan, ayakta tedavi ile sonuçlanan iş kazaları genellikle kayıt altına alınmamaktadır. İş Teftiş Kurulu Başkanlığınca 2013 yılında yapılan Metal İşkolunda İş Sağlığı ve Güvenliği Programlı Teftişi kapsamında teftişinde gidilen 79 işyerinde; elektrik konusunda tespit edilen noksan sayısı 68 dir. 2014 yılında yapılan Ana Metal Sektöründe İş Sağlı̆̆ı ve Güvenliği Programlı Teftişi kapsamında teftişine gidilen 326 işyerinde; elektrik konusunda tespit edilen noksan sayısı 362 olmuştur. Tespit edilen mevzuata aykırılıklara bakıldığında; kullanılan ekipmanların özellikli ve çeşitliliğin çok olduğu, çalışma ortam ve koşullarının elektrik tesisatına zarar verme potansiyelinin yüksek olduğu ve düzenli bakımlarının yapılmadığı anlaşılmaktadır $[3,4]$.

Bir işyerinde amaç iş kazası yaşanmamasıdır. Risk değerlendirmesi hazırlanırken kullanılan en önemli veri, geçmişte yaşanmış iş kazaları ve ramak kala olaylardır. Ayrıca termin sürelerinin belirlenmesi, hangi riskin daha önce çözülmesi gerektiği vb. konularda da problemler yaşanmaktadır. Uzmanlık ve meslek farklılıkları, zararsız olarak görülen ramak kala olaylar ve hafif yaralanmalı kazaların incelenmemesi, risk değerlendirme ekibine mali konularda yapılan baskılar sonucu kararlar daha çok problemi anlık olarak çözmeye yönelik (uyarı işareti, kişisel koruyucu donanım, vb.) olmakta, kazaların ana sebeplerin çözümü uzun vadeye bırakılmaktadır. Ancak çalışan herkesin kullandığı bir enerji kaynağının sebep olacağı bir kazada kişisel koruyucu donanım ya da uyarı levhası kullanımı etkili olmayabilir. 


\section{0}

Koruyucu donanımları ile tasarlanmış bir ekipmanın; bakım esnasında koruma bağlantıları sökülebilir ya da zarar verilebilir. Böylece koruyuculuk özelliği kaybolabilmektedir. Ekipmanı kullanan çalışanın bilgisizliği, enerjinin makine kontrol panelinden değil de elektrik panosundan açılıp kapatılmak suretiyle kontrol edilmesi; çalışanın elektrik akımına maruziyetine neden olabilmektedir. Örneğin; bir metal işleme fabrikasında bakım onarım yapan bir tekniker makinelerin arasında kalan panoya ulaşmaya çalışırken; metal aksam ile pano arasında iletken görevi görmüş ve elektrik akımına maruz kalmıştır. Çalışan anında bayılmış ancak hemen fark edilmediği için kaza çalışanın ölümü ile sonuçlanmıştır. Bu kazada; makinenin pano yerleşiminin yanlış olması, enerjinin kesilmeden bakımın yapılması, iş sağlığı ve güvenliği eğitim ve talimatlarına uyulmaması, etiketleme kilitleme sisteminin uygulanmaması vb. durumlar kaza sebebi olarak gösterilmektedir. Bir başka kaza da ise kaynak işi ile uğraşan bir çalışanın aniden yere düştüğü görülür. Hemen müdahale edilir ancak çalışan kurtarılamaz. Kaza incelendiğinde kaynak makinesinin şasesinin metal bir çubuk üzerine punta atılmak suretiyle yapıldığı görülmüştür. Kaynak makinesinin şasesine temas edilmesi üzerine çalışan elektrik akımına maruz kalmıştır. Bu kazada; makine bakım onarımının düzgün yapılmaması, denetimde bulunan eksiklikler, çalışanın iş sağlığı ve güvenliği eğitiminin olmaması vb. sebepler bulunmaktadır.

Çalışanlar ve sorumluların ramak kala olayların ve ufak çaplı iş kazalarının önemini bilerek hareket etmesiyle aslında kazalar önlenebilir.

Yapılan çalışmada elektrik kazasına sebep olan etmenlerin tablosu oluşturulmuş ve tablodan metal sektöründe görülen maddeler seçilerek uzman kişilerin bu sebepleri hiyerarşik düzende önceliklendirmeleri istenmiştir. Uzman kişilerin sıralaması sonucunda hangi etmenin daha öncelikli olduğu sonucuna ulaşılmıştır.

\section{LİTERATÜR ARAŞTIRMASI}

Elektrik kazaları üzerine birçok araştırma yapılmıştır. $\mathrm{Bu}$ araştırmaların birçoğu ölümcül kaza ya da yaralanma oranının yüksek olması sebebiyle inşaat sektörü ya da elektrik iletim ve dağıtım işlerinde yapılmıştır. Araştırmalara göre bu işyerlerinde elektrikçiler ve yüksek gerilim hattı tamircileri en riskli grup olmuştur. Tüm sektörlerde elektrikle doğrudan çalışma halinde olan elektrikçilerin; kaza geçirme riski yüksektir [5,6]. Diğer çalışan olarak kabul edilebilecek endüstriyel makine operatörleri, elle tutulan iş ekipmanı kullanıcıları, makine tamircileri, kaynakçılar vb. gibi çalışanların elektrik akımına maruz kalma riskinin de çok yüksek olduğu yapılan araştırmalarla gösterilmiştir $[7,8]$. Çalışmamızda elektrik kazalarında inceleme alanı metal sektörü olarak seçilmiştir. Metal sektörünün seçilmesinde diğer çalışanlar olarak sınıflandırılan kaynakçı, operatör vb. sektördeki ana meslek gruplarından olması, Elektrik enerjisinin sektörün her noktasında aktif olarak kullanılmas1 vb. etkili olmuştur.

İş kazası istatistiklerinde genel olarak çalışanın yaşı, kazanın oluş saati, kayıp iş günü, gibi bilgiler çalışan kayıtlarına ulaşılabilmesi açısından en çok tercih edilen veriler olmuştur. Ceylan; Türen ve Gökmen; yaptıkları çalışmalarda kaza geçiren çalışanların yaş, tecrübe, cinsiyet vb. yönden durumlarını inceleyerek; yaşlanma arttıkça iş kazalarının arttığı ancak 44 yaşından sonra kaza oranında düşme yaşandığı, erkeklerin kadınlara göre daha çok kaza geçirdiği sonuçlarına ulaşmışlardır $[9,10]$. Jeong tarafından yapılan çalışmada ölümcül ve ölümcül olmayan kazalarda yaş, tecrübe vb. gibi verilerin farklılık gösterdiği görülmüş, büyük firmalarda kaza sayısının daha düşük olduğu tespit edilmiştir [11]. Zhao vd. tarafından yapılan çalışmada Amerika'da inşaat sektöründe yaşanan elektrik çarpmalarına bağlı kazalarda yapılan incelemelerde; uygunsuz çalışma ortamların- 
dan kaçınmak adına işverenlik tarafından bir değerlendirme yapılmadığı tespit edilmiştir [5]. Williamson ve Feyer ise çalışmada kaza sebepleri incelemiş ve kaza geçiren çalışanların genellikle yanlış yerlerde durdukları, çalışma alanlarının etraflarında korunma olmadığı ve bu nedenle aktif parçalara temas edildiği görülmüştür [12]. Bikson ve Ichskawa maruz kalınan elektrik akımının büyüklüğünü irdelemiştir $[13,14]$. Ichskawa çalışmasında meydana gelen iş kazaların birçoğunun $100 \mathrm{~V}$ ile $200 \mathrm{~V}$ arasında olduğunu göstermiştir [14]. Thomée ve Jakobsson kaza geçiren 25 çalışan ile yaptıkları araştırmada elektrik kazasının birçok fiziksel ve psikolojik etkisi olduğunu; bazı çalışanların hayatının değişmesine neden olduğunu belirtmektedir [15]. Panaro ve Amatucci tarafından elektrik kazaları üzerine yapılan istatistiki çalışmanın sonucunda kazaya neden olabilecek elektrik kaynağı ile ilgili hiyerarşik tablo oluşturulmuştur [16]. Çalışmamızda tek bir modele ve veriye bağlı kalınmayarak, kaza sebepleri geniş çaplı bir yaklaşımla belirlenmiştir.

Risk değerlendirmesi aşamasında iş kazalarının ya da çalışan görüşlerinin veri olarak kullanımı giderek yaygın hale gelmektedir. Özdemir çalışmasında kazaların genel etkenlerini bulmak amacıyla seçtiği metal sektörü çalışanlarına anket uygulamıştır [17]. İş sağlığı ve güvenliği konusunda sorular sorarak bilgi düzeylerini ölçmüş; çalışanların eğitim aldığı halde bilgilerinin kalıcı olmadığı sonucuna ulaşılmıştır. Akalp vd. yaptı̆̆ı çalışmada metal sektöründe çalışan kadınların; ortamdaki tehlikeler hakkındaki bilgi durumlarını tespit etmeye çalışmış ve ölüm algısıyla güvenlik önlemlerine olan farkındalığın negatif bir eğride buluştuğu sonucuna varılmıştır [18]. Roberts Elektrik güvenliğinin artırılması için yönetim sistemlerinin kullanımının etkili olduğunu belirtmektedir [19]. Bu çalışmada güvenlik önlemlerinin alınması, eğitim verilmesi vb. gibi aksiyonlarda, kaza olma olasılığı göz önünde bulundurularak bir sıra- lamaya tabi tutulması ve yapılan işlemlerin bu şekilde uygulanması gerektiği gösterilmektedir.

Bazı çalışmalarda iş kazaları istatistiki olarak değerlendirilmiş, elde edilen sayısal sonuçlar risk değerlendirmesinde çarpan olarak kullanılmıştır [20,21]. Risk değerlendirmesi sürecinde şiddet belirleme gibi faktörlerin kantitatif olması amaçlanmıştır. Chi vd. akış diyagramı yöntemi kullanarak maruziyet türünden itibaren kaza sebeplerini inceleyerek kök nedene ulaşıp yüzde olarak skor hesabı yapmışlardır [22].

Bir iş kazasının meydana gelmesinde ekipman, organizasyon ve insan faktörlerinden en az bir tanesinde hata meydana gelmesi gerekir. Williamson ve Feyer; ekipman, organizasyon ve insan faktörünün tamamı göz önünde bulundurarak elektrik kazalarının önlenmesi için araştırma yapmış; uygunsuz çalışma koşullarının ve insan faktörünün ölümcül kazalarda ana neden olduğu sonucuna ulaşmıştır [12]. Mohla vd.; çalışmasında elektrik sistem tasarımının güvenlik için önemini vurgulamış [23]; McClung ve Hill çalışmalarında elektrik tesisatının tasarım teknikleri için yeni uygulama önerileri sunmuşlardır [24]. Bu çalışmada da elektrik tesisatında meydana gelecek hata zincirinin herhangi bir noktasında; esas problemi oluşturacak hatanın bertaraf edilmesi amacıyla alınabilecek önlemler sıralanmıştir.

\section{METODOLOJİ}

Analitik hiyerarşi süreci (AHP) çoklu karar verme metotlarından birisidir. İlk olarak Thomas L. Saaty tarafından oluşturulmuştur. Saaty bir olayı anlamak için elde edilen bilgilerin çok oluşunun ya da konu hakkında çok fazla bilgi sahibi oluşun karar verme aşamasında avantaj oluşturmadığını belirtmektedir [25]. Sezgisel olarak yaklaşımlarla problem çözmede; eldeki verilerin kullanışlılığı hakkında doğru karar verilemeyebileceğinin ve bu durumun birçok örneği 
olduğunu belirerek karar verme aşamasına matematiksel yaklaşılması gerekliliğini savunmaktadır. Analitik hiyerarşi sürecinin; bir olaydaki paydaşlar ve etkilenecek gruplar göz önünde bulundurularak, düşünceleri formülize edip en iyi sonuca ulaşmaya yardımcı olacağını belirtmektedir.

Analitik hiyerarşi süreci birçok alanda karar verme işlemi esnasında kullanılmaktadır. Sürecin İşs sağlığı ve güvenliğinde kullanılması ise çok yaygın değildir. Caputo vd. endüstri makinalarında kullanılacak olan güvenlik ekipmanlarının birden çok alternatif arasından en fiyat- fayda dengesini sağlayacak olanın seçiminde kullanmıştır [26]. Fang vd. AHP'yi inşaatlarda kullanılacak en uygun iskelenin seçiminde kullanmıştır [27]. Abinbakhsh vd. yeni bir inşaat projesine başlanmadan önce iş sağlığı ve güvenliği konusunda meydana gelen iş kazası çeşitlerini fiyat-fayda dengesini de göz önüne alarak AHP ile öncelik sırasına koymayı; bu sayede bütçe planlanmasının ona göre yapılmasını amaçlamıştır [28]. Badri vd. AHP'nin kullanılmasıyla bir risk skoru hesabı oluşturarak iş sağlığı ve güvenliği risk değerlendirmesi esnasında kullanılabilirliğini göstermiştir [29]. Kaza sebeplerinin kendi içerisinde sıralanmasına dair herhangi bir çalışmaya rastlanmamıştır.

Analitik Hiyerarşi Metodu ile karar verme aşaması şu şekilde olmaktadır: Önceden belirlenmiş olan kriterler, alt kriterler ve alternatifler ile hiyerarşik bir yapı oluşturulur. Uzman bir kişi ya da bir grup tarafından alternatiflere göre kriterlerin değerlendirmesi yapılır. En sonunda yapılan seçim sonuçları sayesinde kriterlerin ağırlık değerlerine göre sıralaması yapılır. Bir den fazla seçeneğin olduğu durumlarda amaca göre en öncelikli kriter belirlenmiş olur.

Hiyerarşik düzen gösterimi kriter, alt kriter ve alternatiflere toplu bir bakış yapılmasını sağlar ki değerlendirmeyi yapacak olan uzman kişi daha homojen ve doğru şekilde karar verebilir. Kıyas yapılan değerler sözlü ifadelerle yapılabileceği gibi (eşit, az üstün, çok üstün, mutlak üstün vb gibi.); sayısal değerler (1,3,5,7,9 vb.) kullanılarak da yapılabilmektedir [25].

Önceliklerin belirlenmesi aşamasında karar verilebilmesi için bazı adımların uygulanması gerekmektedir [30]. Öncelikle problem tanımlanmalı ve hangi tür bilgi isteniyorsa karar verilmelidir. Hiyerarşik yapının en üst hedeften en alttaki yapı elemanına kadar düzenlenmesi gerekmektedir. Kriterler, alternatifler ve alt kriterlerin hepsinin bu yapıda görünmesi sağlanmalıdır. Oluşturulan hiyerarşik yapıya göre ikili karşılaşıırma matrisleri hazırlanmalıdır. $\mathrm{Bu}$ matrislerde en alttan başlanarak önem dereceleri verilmelidir. $\mathrm{Bu}$ derecelere göre ise ahp matematiği kullanılarak ağırlık vektörleri ve önem sıraları belirlenmelidir.

Tablo 1: Karar verme ölçeği ve açıklaması

\begin{tabular}{lll}
\hline Önem Derecesi & Tanım & Açıklama \\
\hline 1 & Eşit Önemde & iki durumda olay üzerinde eşit derecede etkili \\
3 & Orta derecede önemli (az üstün) & Bir durum diğerine göre hafif seviyede daha etkili \\
5 & Oldukça Önemli (Fazla Üstün) & $\begin{array}{l}\text { Bir durum diğerine göre daha çok etkili } \\
\text { Bir durumun etkileme miktarı diğerine göre çok } \\
\text { daha baskın }\end{array}$ \\
7 & Çok Önemli (Çok Üstün) & $\begin{array}{l}\text { Belirtilere göre bir durumun etkileme miktarı diğe- } \\
\text { ine göre olabildiğince yüksek seviyede. }\end{array}$ \\
9 & Son Derece Önemli (Mutlak Üstün) & Ara değerler gerektiğinde kullanılır. \\
$2,4,6,8$ & Ara Değerler (iki Yakın Değerlendirme İ̧̧in) & Daha az önemli olunduğu durumlarda kullanılır. \\
KARŞIT DEĞERLER & 1/x Diğerine Göre Önem Derecesi Az &
\end{tabular}


Saaty'nin önerdiği numaralandırma değerleri Tablo 1'de belirtilmektedir.

İkili karşılaştırma matrisi üzerinde önceliklendirme yapılırken bir kriter diğeriyle kıyaslanır. Örneğin; Şekil 1'deki karşılaştırma matrisinde A1, A2 ve A3 değerleri kıyaslanmaktadır. Oluşturulan matris Tablo 2'deki gibi olacaktır. Burada öncelikle A1 ve A2 kriteri kıyaslanır. Hangi kriter daha üstünse ona göre numara verilir ve matrise yerleştirilir. Bu kıyaslamaya bütün kriterler boyunca devam edilir. Değerlendirme sonucunda önceliklendirme yapılır ve bu sıralamanın tutarlılığı belirtilir. Tutarlılık oranı 0.1 'in altında olan sonuçlar dikkate alınır.

Şekil 1: Elektrik İş Kazalarına Neden Kriterler

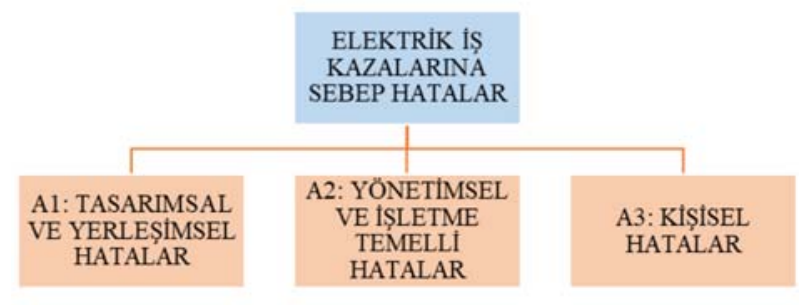

Tablo 2: A1, A2 ve A3 Kriterleri Karşılaştırma Matrisi

\begin{tabular}{c|ccccc} 
& A1 & A2 & A3 & $\begin{array}{c}\text { Önem } \\
\text { Sıralaması }\end{array}$ & $\begin{array}{c}\text { Tutarlılık } \\
\text { Oranı }\end{array}$ \\
\hline A1 & 1 & $1 / 3$ & $1 / 7$ & 3 & \\
A2 & 3 & 1 & $1 / 3$ & 2 & $\mathbf{0 , 0 0 6 6 9}$ \\
A3 & 7 & 3 & 1 & 1 &
\end{tabular}

AHP ile bir hiyerarşik düzenin değerlendirmesinde uzman grup tarafindan da karar verilebilmektedir. Bu noktada 2 önemli durum bulunmaktadır. İlk olarak katılımcıların verdiği bireysel kararların nasıl tek bir grup kararlarına dönüştürüleceği diğer bir nokta ise grup kararının bireysel kararlardan nasıl oluşturulacağıdır. Bunun için Saaty iki yöntem tavsiye etmiştir [30]. İlk olarak grup üyelerinin seçim esnasında bir arada bulunup değerlendirme yapılır- ken ortak bir karara varılarak değerlendirme yapılması, ikinci olarak ise grup üyelerinin bireysel kararlar verip bu kararların geometrik ortalaması alınarak ağırlıkların ve tutarlılık oranının hesaplanması. Genellikle grup üyelerinin farklı düşüncelerde olması durumunda ortak bir karara varılamama gibi bir ihtimal söz konusu olduğundan ikinci husus daha kullanışlı olmaktadır.

Bu çalışmada; İş Teftiş Kurulu Başkanlığının verileri, FACE (Fatality Assessment And Control Evaluation) Programı verileri, Accident İnvestigation Summary verileri, Google Alert sistemi aracılığılla internet gazetelerinde yayınlanmış ve içerisinde 'electrical shock', 'elektrik çarpması', 'electrical incident' kelimeleri geçen haberler kullanılarak 40 adet Metal Sektörü işyerinde meydana gelmiş elektrik kaynaklı iş kazası incelenmiştir [3,4,31,32].

Elektrik kazaları için sebep tablosu oluşturulurken önceki yapılan çalışmalar sonucu elde edilen kaza nedenleri $[10,33,5,34,6]$ yasal mevzuatta zorunlu tutulan maddeler, çalışanların psikolojik fizyolojik durumları üzerine yapılan araştırmaların sonuçları $[9,35,10,17]$ incelenerek oluşturulmuştur.

Elektrik iş kazasına sebep olabilecek 3 temel faktör bulunmaktadır. İlk faktör tasarımsal ve ekipman yerleşiminden kaynaklıdır. Yapılan tesisat yada ekipman tasarımlarının mevzuatlara uygun olmaması, yapılacak olan işin niteliği ile bağdaşmaması, düzgün şekilde kurulmaması gibi nedenler bu kategoride yer alabilir. İkinci faktör yönetimsel ve işletme temelli hatalardır. Buna organizasyon hatası da denilebilmektedir. Burada kazalar; yasal ve bağlayıcı hükümlerin verdiği görev ve sorumlulukların işveren kuruluşlarca yerine getirilmemesi nedeniyle olmaktadır. Üçüncü faktör ise çalışanın kendi ruhsal durumu ya da ihmalkâr davranışları sebebiyle meydana gelen faktörlerdir. Burada belirtilmesi gereken önemli bir husus bulunmaktadır. İş 
sağlığı ve güvenliğinde toplu korunma daima kişisel koruyucu donanıma göre öncelikli olarak sağlanır. Burada ki amaç güvenliği çalışanın inisiyatifine bırakmamaktır.

Yapilan kaza incelemeleri sonucu kazalara sebep olan olaylar kaza sebep tablosundaki sebeplerle eşleştirilmiştir. $\mathrm{Bu}$ eşleştirmeler sonucu tablo üzerinde sebepler arasında bulunmayan maddeler sadeleştirilmiş ve AHP hiyerarşik tablosu oluşturulmuştur. Hiyerarşik düzen içerisinden ikili karşlaşııııma matrisleri oluşturulmuştur.

İş Teftiş Kurulu Başkanlığında görevli branşı Elektrik Elektronik Mühendisliği olan 8 iş müfettişine oluşturulan karar matrisleri üzerinden önceliklendirme yapmaları istenmiştir. Müfettişler tarafından verilen karar ölçütlerinin geometrik ortalaması ile grup karar matrisi oluşturulmuştur. Alınan sonuçlar yazılım üzerinde işlenerek grup karar matrisi sonuçları elde edilmiştir.

\section{BULGULAR}

Çalışmada elektrik kaynaklı iş kazalarının meydana gelmesine sebep olan en öncelikli faktörün bulunması amacıyla AHP yöntemi uygulanmış; kriterlerin sıralanmasında iş müfettişlerinin uzman görüşü esas alınarak uygulama verisi elde edilmiştir. Elektrik iş kazasına sebep olabilecek 3 temel faktör belirlenmiştir; Tasarımsal ve yerleşimsel hatalar, yönetimsel ve işletme temelli hatalar ve kişisel hatalar. $\mathrm{Bu}$ faktörler iş kazası nedenleri içinde temel faktör olarak belirtilebilir. Bu faktörlerin belirlenmesinden sonra her bir ana faktör için alt kriterler oluşturulmuştur. Alt faktör 1 için 3 alt kriter, alt faktör 2 için 7 alt kriter, alt faktör 3 için 3 alt kriter belirlenmiştir. Her bir alt kriterinde kendi içerisinde alt kriterleri bulunabilmektedir. Elektrik kazasına sebep olabilecek faktör tablosunda toplam 46 alt kriter bulunmaktadır (Şekil 2).

Kaza incelemesi esnasında verilerin özellikle kişiler hakkında bilgilerin bulunduğu kısımların doldurulmadığı görülmüştür. Bu sebeplerin önceliklendirmeye alınmasının uygun olmayacağı kararı verilmiştir. Uzman görüşüne sunulan hiyerarşi tablosu oluşturulmadan önce eksik olan kısımlar çıkarılmıştır. İkili karşılaştırma matrisleri kalan faktörler üzerinden oluşturulmuştur.

Elektrik iş kazalarına sebep hatalar Şekil 2'deki kaza sebebi tablosunda belirtilmiştir. Tablo 3'te kodlara karşıllık gelen açıklamalar belirtilmiştir.

Kaza incelemeleri esnasında veri eksikliği olan sebeplerin yanı sıra; incelenen 40 adet kaza arasında dolaylı yoldan kazaya sebebiyet verecek maddeler de tespit edilmiştir.

Şekil 2: Elektrik İş Kazasına Sebep Hatalar Hiyerarşik Yapısı

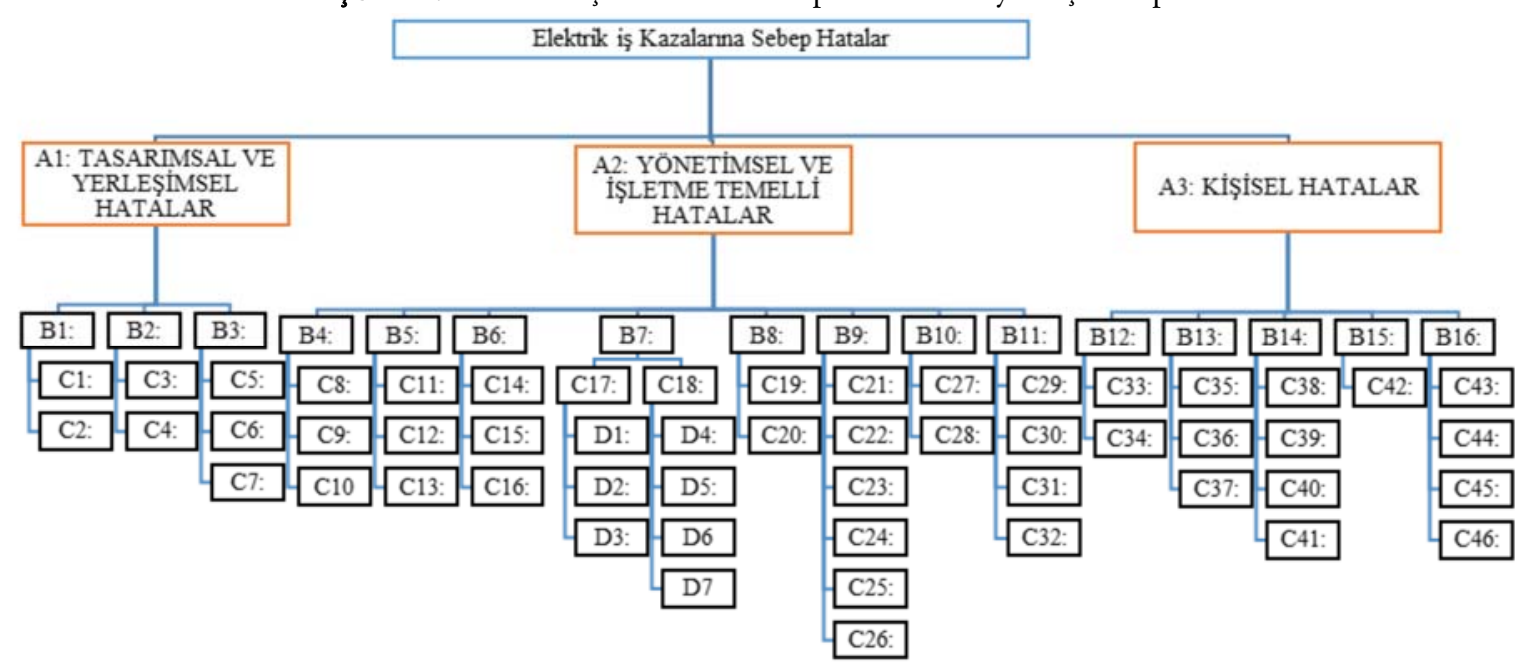


Şekil 3: Uzman Görüşüne Sunulan Hiyerarşik Yapı

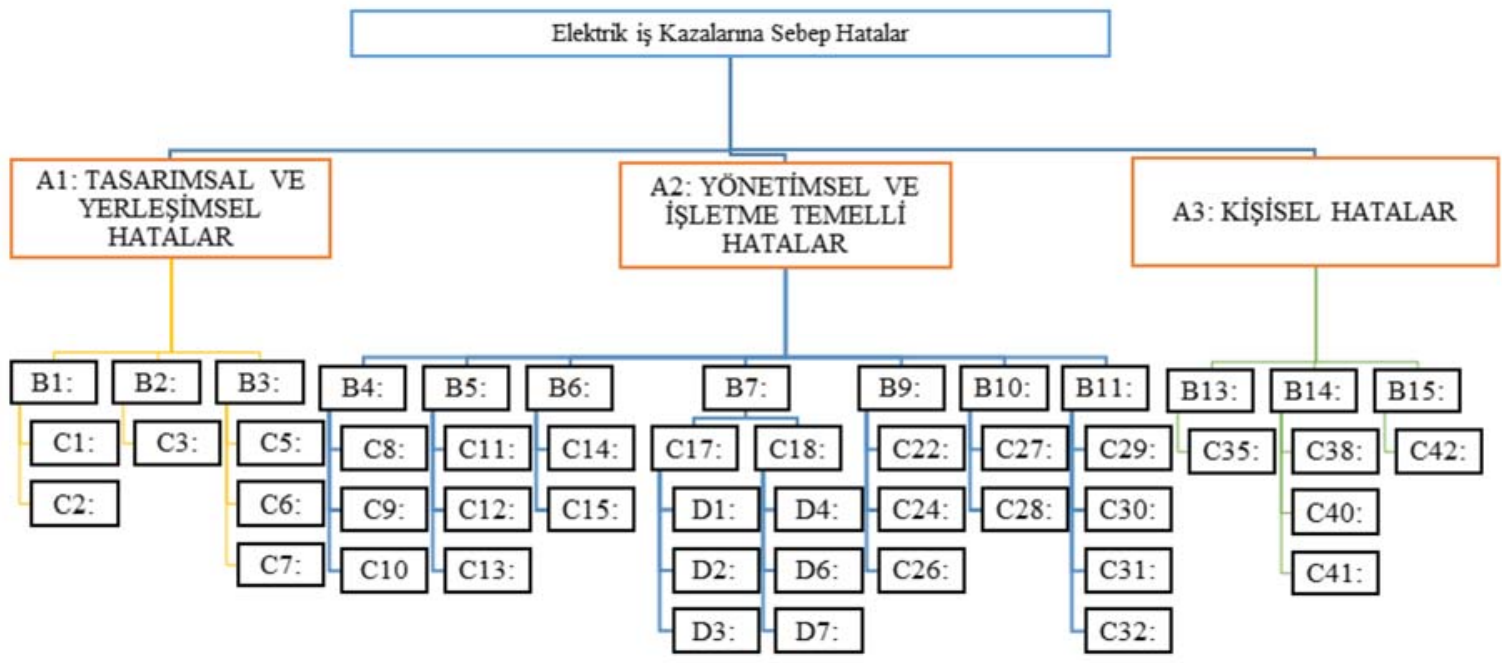

Dolaylı nedenlerin işletme koşulları ve çalışan profiline göre kararsız bir şekilde değişmesi, dolaylı sebeplerin hiyerarşik güvenirliğe olumsuz etkisi olacağı kanısını oluşturmuştur. Bu nedenle; dolaylı sebepler ile doğrudan kaza sebepleri ayrılmıştır. Sebep tablosunda yapılan sadeleştirmeler sonucu Şekil 3'te görülen AHP hiyerarşik tablosu oluşturulmuştur.

Elde edilen AHP hiyerarşik tablosu ile AHP için kullanılan Expert Choice 2000 yazılımında hiyerarşi tablosu ve grup karar matrisi oluşturulmuştur [36]. Oluşturulan karş1laştırma matrisleri her uzman için ayrı ayrı doldurulmak suretiyle sebepler değerlendirilmiştir. Değerlendirme sonucunda 8 uzman değerlendirmesi, yazılım aracılığıyla tek bir matris yapısı altında geometrik ortalama yöntemi kullanılarak birleştirilmiştir.

Uzman değerlendirmesinin birleştirilmesi ile ortalama ağırlık değerleri, normalleştirilmiş değerler, tutarlılık oranı ve öncelik sıralaması sonuçları elde edilmiştir. Sonuçlar Tablo 4'te listelenmiş olarak bulunmaktadır.

Değerlendirme sonuçları en üst hiyerarşik değerden başlanarak yorumlandığında önceliklendirme sırası
A1:Tasarımsal ve Yerleşimsel Hatalar, A2: Yönetimsel ve İşletme Temelli Hatalar ve A3: Kişisel Hatalar olarak belirlenmiştir. Tutarlılık Oranı 0,05 çıkarak kabul edilebilir seviyenin altında bulunmaktadır. Bu noktada Kişisel Hatalar bölümünde yapılan sadeleştirmeler ile sonuç arasında herhangi bir etkileşim bulunmamaktadır.

Tasarımsal ve Yerleşimsel Hatalar faktöründe İşe Uygun Teçhizat /Tesisat Seçimi Ve Kurulumu alt kriteri ilk sırada; Projelerin Mevzuata Uygunluğu Ve Uygun İnşası son sırada bulunmaktadır. Yönetimsel ve İşletme Temelli Hatalar faktörü için yapılan alt kriter önceliklendirmesinde; Ekipman Seçiminin Uygunluğu 1. sırada, Bakım/ Onarım Ve İyileştirme Hatası 2. sırada bulunmaktadır. Planlama Ve Çalışma Talimatları 6. sırada Verimli Ve Güvenli Çalışma Planı ise 7. sırada bulunmaktadır. Bu önceliklendirmenin tutarlılık oranı 0,02 çıkmış olup kabul edilebilir seviyenin altında bulunmaktadır. Ağırlık değerlerine bakıldığında Çalışanın Denetim ve Gözetimi ile Eğitim ve Bilgilendirme Kriterleri 0,001 farkla sıralanmıştır.

Kişisel Hatalar faktörü için alt kriter karşılaştırmasında 3 alt kriter bulunmaktadır. Çalışanın Prosedürlere Uyması kriteri 1. sırada, İş Bilgisi/Tecrübe kriteri 2. sırada, Eğitim 


\section{2}

Alma kriteri ise 3. sırada yer almıştır. Tutarlılık oranı 0,00686 çıkmış olup kabul edilebilir seviyede bulunmaktadır. Kişisel Hatalar bölümünde sadeleştirme yapılmış olması nedeniyle bazı kriterler değerlendirilmemiştir.

Şekil 3’te görülen C17:İş Sağlığı ve Güvenliği Eğitimi Verme ve C18: Mesleki Eğitim alt kriterinde bulunan D1,D2,D3,D4,D6,D7 kodlarına karşılık gelen değerler iş sağlığ1 ve güvenliği eğitimi kapsamında ve mesleki eğitim kapsamında alınan çeşitli eğitimlerdir. Burada tutarlılık oranına bakıldığında 0,1 'den büyük olduğu görülmektedir. $\mathrm{Bu}$ değer çalışana verilecek eğitim konusunda görüşlerin tutarsız olduğu anlamına gelmektedir. Ayrıca hiyerarşik tabloda bir üst kriter değerlendirilmesinde C17 ve C18 kriterlerinin kıyaslanmasında 2 kriter kıyaslandığı için tutarlılık oranı ' 0 ' olarak çıkmaktadır. Eğitim başlığının bağlı bulunduğu B7 kriteri ise kendi sınıfında 7 kriter arasında 4. sırada önemli kabul edilmiştir.

Organizasyon bakımından 6. Sirada bulunan 'B11: Planlama Ve Çalışma Talimatları' diğer kriterlere göre 6. sırada seçilmiştir. Alt kriterlerine bakıldığında 'C30: Risklerin belirlenmemesi/eksik risk değerlendirmesi' nin ilk sırada 'C31: Güvenli çalışma talimatı oluşturulmaması/ eksik olması' nın ise en son sırada olduğu görülmüştür.

\section{TARTIŞMA VE SONUÇ}

Çalışmada literatürde beraber değerlendirilmemiş olan metal sektörü ve elektrik kazaları incelenmiştir. Elektrik kazalarına sebep olabilecek nedenler listelenmiş; Metal işyerlerinde meydana gelen kazaların incelenmesiyle bu sebepler arasından sadeleştirme yapılmıştır. Uygulama aşaması kaza sebeplerinin hiyerarşik bir düzende sıralanmasıyla başlamıştır. Bu hiyerarşi iş sağlı̆ğ ve güvenliği alanında teftiş yapmaya yetkili ve branşı elektrik elektronik mühendisliği olan iş müfettişleri tarafından AHP karar tablosu kullanılarak önceliklendirilmiş ve sonuçlar elde edilmiştir.
Sonuçlara bakıldığında; işe ve işin şartlarına uygun şekilde tesisat, tasarım ve inşanın yapılmasının önemi kat kat vurgulanmaktadır. Organizasyon boyutunda yapılacak iyileştirmelerin; çalışanın hatasına karşı alınacak tedbirlerden daha etkili olduğu sonucu görülmektedir. Bu durumda bir iş kazası meydana geldiğinde çalışma talimatnamelerinin varlığı daha önce sorgulanmalıdır. 6331 Sayılı İş Sağlığ1 ve Güvenliği Kanunu Madde 4 ve Madde 5 'te belirtildiği gibi “işverenin önlem alması” hususu uzman değerlendiriciler tarafından da öncelik sıralamasında önde gösterilmiştir.

İşverenler; işyerlerini kurarken yapılacak işe gerekli ekipmanların optimizasyonundan önce faaliyet göstereceği binaların kiralanması yoluna gitmektedir. Ancak kiralama esnasında mali boyut önemli olduğundan yapılacak işin kiralanan alana uygunluğu göz ardı edilebilmektedir. Bu durumda elektriksel açıdan tesisat uygunsuzluğu ilk ortaya çıkan problemdir. Araştırma sonuçlarına bakıldığında en öncelikli kaza sebebi olan Tasarımsal ve Yerleşimsel Hatalarda; 'İşe Uygun Teçhizat /Tesisat Seçimi Ve Kurulumu' alt kriterler arasında ilk sırada görülmüş tesisatın 'Projelerin Mevzuata Uygunluğu Ve Uygun İnşası' ise son öncelikli sebep olarak görülmüştür. Buradan tesisatın mevzuata uygunluğunun önemsiz olduğu değil; öncelikle hangi işin yapılacağına karar verilmesi ve buna göre hangi ekipmanların kullanılacağının belirlenmesinin gerekliliği anlaşılmalıdir.

Çalışmada; organizasyon yapısında çalışanlara verilecek eğitimlerden önce ekipman seçiminin yapılacak olan işe uygun olması, bu ekipmanların bakım onarımının yetkili kişilerce yapılmasını sağlayacak önlemlerin alınması, Kontrol ve denetim düzeninin oturtulması ile ilgili çalışmaların öncelikli olarak giderilmesi gerektiği sonucuna varılmıştır. Eğitim verilirken çalışanlara verilecek eğitimin işyeri ortamı, koşulları vb. durumlar göz önünde bulundurulması ve 
öncelikle işe uygun mesleki eğitimdeki eksikliğin giderilmesi gerekmektedir. Meslek hakkında bilgisi olmasının daha öncelikli olduğu yargısına varılmıştır. Ancak mesleki eğitim boyutunda alınacak eğitimlerle ilgili olarak tutarlı bir sonuca ulaşılamamıştır.

Kişisel hataların sıralamada en sonda yer alması ulusal ve uluslararası boyutlarda iş sağlığı ve güvenliği mevzuatı hükümleriyle uyuşmaktadır (örneğin; 6331 sayılı kanun madde 4,5). Ayrıca kaza sebebi tespiti sürecinde yapılan iş kazası incelemeleri esnasında organizasyonel boyutta birden fazla eksikliğin bulunduğu görülmüştür. Örneğin elektrik panosunun yanlış yere konulmasının yanı sıra eğitim almamış personele görev verilmesi, yalıtım vb. önlemlerin alınmaması gibi nedenlerin kaza sebebi olduğu görülmüştür. Ayrıca birçok kazada risklerin değerlendirilmediği, güvenli çalışma planlarının oluşturulmadığı da tespit edilmiştir. Kişisel Hatalar ile iş kazası konusunda yapılan bazı çalışmalarda da çalışmamızla tutarlı sonuçlar olduğu görülmektedir. Önlem alırken tasarım ve organizasyon boyutunun halledilmesiyle çalışana yönelik çalışmaların yapılması gerektiği anlaşılmaktadır $[17,37,38]$. Yapılan anketlerde çalışanların çalışma saatleri ve koşulları hakkında şikayetlerde bulunulduğu; güvensiz çalışmanın organizasyon tarafından desteklendiği ve çalışanın bana bir şey olmaz psikolojisi ile yaklaştığı görülmüş̧ür.

Analitik Hiyerarşi Sürecinin iş kazası modellemelerinde örneği çok bulunmamaktadır. Bu çalışmada AHP; kriterlerin uzmanlar tarafından değerlendirmesi amacıyla kullanılmıştır. Karmaşa içerisinde bulunan iş kazası sebeplerinin önceliklendirilmesi yapılmıştır. Böylece risk değerlendirme aşamasında hangi eksiklik ya da noksanlıkların daha önce giderileceğine yardımcı olunması amaçlanmıştır. Sıralamalar, belirli metotlar kullanılarak skor hesaplaması yapılan risk değerlendirmelerinde fiyat-fayda, kaza-şiddet dengesi gibi koşullar aranarak termin süresi hesaplamasında da kullanılabilir. Çalışma; meslek branşı elektrik olsun olmasın işyeri sahipleri, iş güvenliği uzmanları vb.'nin elektrik kazasını önlemesi açısından atacağı adımlarda daha emin olmalarına yardımcı olabilecektir.

Çalışmada çok fazla kriterin aynı anda değerlendirilmesi nedeniyle puanlamada zorluklar yaşanmıştır. 'Kişisel hatalar’ başlı̆̆ının önceliklendirilmesi; verilerin paylaşılmaması ve kaza incelemelerinde daha çok teknik sebepler üzerinde durulması nedeniyle kendi alt hiyerarşik düzeninde etkin şekilde değerlendirilememiştir. Ancak bu durum ana kriter değerlendirmesinde herhangi bir olumsuz etkiye neden olmamıştır. Uyguladığımız model farklı sektörlerde de uygulanabilecek şekilde kolaylıkla güncellenebilir. Gelecekte yapılacak olan çalışmalarda kriter ve alt kriterlerin dağılımı sektöre özel olarak sıralanabilir yada risk değerlendirmesinde skor hesaplanması amacıyla kullanılabilir. Ana kaza sebebi tablosu kullanılarak tüm sektörlerin tek bir matris üzerinde yorumlanmasıyla da yapılabilir. Ancak her sektörün çalışma koşullarının kazaya etkisi göz önünde bulundurulmalıdır. Veri eksikliğinde esas sebebin kazaların sebeplerinin ülkemizde ayrıntılı olarak paylaşılmaması olduğu düşünülmektedir. Bu sorunun aşılmasıyla daha fazla çalışmanın yapılabileceği düşünülmektedir.

Çalışmada yapılan sıralamalar; işyerinde bulunan eksikliklerin giderilmesinin mali ve zaman boyutu göz önüne alındığında, planlama aşamasında öncelikli olacak risklere hedef alınmasına yardımcı olabilir. Ayrıca eksiklik giderme sürecinde yaşanan zaman kaybının önüne geçilebilir. Örneğin tasarım esnasında hataları olan bir işyerinde organizasyonun alacağı önlemlerin ikinci sırada olduğu yargısından yola çıkılarak; elektrik kaynaklı iş kazalarının önlenmesi açısından belki de tesisatta yapılacak basit bir düzenleme ile tehlikeler büyük oranda ortadan kaldırabilir. 


\section{KAYNAKLAR}

[1] 6331 Sayılı İş Sağlığı ve Güvenliği Kanunu, RG Tarih: 30.06.2012 Sayı 28726.

[2] İnternet: SGK, SGK İstatistik Yıllıkları http:// www.sgk.gov.tr/wps/portal/sgk/tr/kurumsal/istatistik/ sgk_istatistik_yilliklari, adresinden 07/06/2018 tarihinde erişildi.

[3] Çalışma Ve Sosyal Güvenlik Bakanlığı İş Teftiş Kurulu Başkanlığı, "Metal işkolunda iş sağlığı ve güvenliği programlı teftişi”, 2013, Ankara, ÇSGB.

[4] Çalışma Ve Sosyal Güvenlik Bakanlığı İş Teftiş Kurulu Başkanlı̆̆ı, "2014 yılı ana metal sektöründe iş sağlığı ve güvenliği programlı teftişi sonuç raporu”, 2014, Ankara, ÇSGB.

[5] ZHAO, D., THABET, W.,, MCCOY A., KLEİNE B., "Electrical deaths in the us construction: an analysis of fatality investigations", International Journal Of Injury Control And Safety Promotion, Vol 21, No 3, 278-288, 2014.

[6] CHİ, C.F.,, YANG C.C., and CHEN, Z. L., "Indepth accident analysis of electrical fatalities in the construction industry", International Journal Of Industrial Ergonomics, Vol 39, 635-644, 2009.

[7] FLOYD, H. L., "Facilitating application of electrical safety best practices to 'other' workers", IEEE Transactions on Industry Applications, Vol 51, No 2, 1348-1352, 2012.

[8] NEITTZEL, D. K., "Electrical safety basics for nonelectrical personnel", 61St IEEE Pulp \& Paper Industry Conference (PPIC), 2015, IEEE.

[9] CEYLAN, H., "Türkiye'deki elektrik üretim, iletim ve dağııım tesislerinde meydana gelen iş kazalarının analizi”, International Journal Of Engineering Research And Development, Vol 4, No 2, 30-42, 2012,

[10] TÜREN, U., GÖKMEN, Y., "Türkiyede meydana gelen iş kazaları sonucu ölümler işe çalışanların yaş faktörü arasındaki ilişki”, Sosyal Güvenlik Dergisi, Cilt 4, Say1 1, 101-119, 2014.

[11] JEONG, B. Y., "Comparisons of variables between fatal and nonfatal accidents in manufacturing industry", International Journal Of İndustrial Ergonomics, Vol 23, 565-572, 1999.

[12] WILLIAMSON, A., FEYER, A.M., "The causes electrical fatalities at work", Journal Of Safety Research, Vol 29, No 3, 187-196, 1998.

[13] BİKSON, M, "A Review Of Hazards Associated With Exposure To Low Voltages,", 2014.
[14] ICHSKAWA, N., "Statistical accident anaysis and electrical fatality rate in japan, 2002-2011- causes and preventive measures of fatal electrical accidents", IEEE IAS Electrical Safety Workshop, 2015, IEEE

[15] THOMÉE S., JAKOBSON K.; "Life-changing or trivial: Electricians' views about electrical accidents." Work, Vol 60, No 4, 573-585, 2018.

[16] PANARO P., AMATUCCİ S., "Analysis of work accidents with electrical origin.” 2017 IEEE International Conference on Environment and Electrical Engineering and 2017 IEEE Industrial and Commercial Power Systems Europe (EEEIC / I\&CPS Europe), 2017, IEEE.

[17] ÖZDEMIR, S., "Metal imalat sektöründe oluşan kazalarda insan ve altyapı faktörlerinin araştırılması" Yayımlanmamış Yüksek Lisans Tezi, Gazi Üniversitesi Fen Bilimleri Enstitüsü, 2014, Ankara.

[18] AKALP, G., AYTAÇ, S., YAMANKARADENIZ, N., ÇANKAYA, O., GÖKÇE, A., and TÜFEKÇİ, U., "Perceived safety culture and occupational risk factors among women in metal industries: a study in turkey", Procedia Manufacturing, Vol 3, 4956-4963, 2015.

[19] ROBERTS D.T., "Applying risk assessment at the worker level- applications to electrical safety" IEEE Industry Application Magazine, Vol 25, No 1, 18-24, 2019.

[20] MARHAVILLAS, P.K., KOULOURİTIS, D.E., and MITRAKAS, C., "On the development of a new hybrid risk assessment process using occupational accidents' data: application on the greek public electric powr provider"., Journal Of Loss Prevention İn The Process İndustries, Vol 24, 671-687,

[21] GÜRCANLI, G. E., MÜNGEN, U., "Bulanık kümeler ile inşaatlarda yeni bir iş güvenliği risk analizi yöntemi”, İtü Dergisi/d Mühendislik, Cilt 5, Sayı 4, 83-94, 2006.

[22] CHI, C.F., LIN Y. Y., and IKHWAN M., "Flow diagram analysis of electrical fatalities in construction industry", Safety Science, Vol 50, 1205-1214, 2012.

[23] MOHLA, D., MCCLUNG, L. B., and RAFFERTY, N.R., "Electrical safety by design", Petroleum and Chemical Industry Conference, Industry Applications Society 46th Annual, 363-369; 2002, IEEE.

[24] MCCLUNG, L. B., HİLL, D. J., "Electrical System Design Techniques To Improve Electrical Safety", Electrical Safety Workshop (ESW), IEEE IAS, 2010, IEEE.

[25] SAATY T. L., "Decision making with the analytic 
hiyerarchy process", International Journal Services Sciences, Vol 1, No 1, 2008.

[26] CAPUTO, A. C., PELAGAGGE, P. M., and SALİNI,P., "Ahp-based methodology for selecting safety devices of industrial machinery". Safety Science, Vol 53, 202-218, 2013.

[27] FANG, D., SHEN, Q., WU, S., and LIUU, G., "A comprehensive framework for aessing and selecting appropriate scaffolding based on alaytic hierachy process", Journal of Safety Research, Vol 34, 589-596, 2003.

[28] ABİNBAKHSH, S., GÜNDÜZ, M., and SÖNMEZ, R., "Safety risk assessment using ahp during planning and budgeting of construction projects", Journal Of Safety Research, Vol 46, 99-105, 2013.

[29] BADRİ, A., NADEAU, S., and GBODOSSOU, A., "Proposal of a risk-factor-based analytical approach for integrating occupational health and safety into project risk evaluation”, Accident Analysis and Prevention, Vol 48, 223-234, 2012.

[30] SAATY T.L., "The ahp: how to make a decision" , European Journal Of Operational Research, Vol 48, 9-26, 1990.

[31] İnternet: Fatality Assessment and Control Evaluation (Face) Program https://www.cdc.gov/niosh/face/ default.html adresinden 07/06/2018 tarihinde erişildi.

[32] İnternet: Accident İnvestigation Search https:// www.osha.gov/tutorials/acci_help.html\#indust adresinden 07/06/2018 tarihinde erişildi.

[33] LIGGETT, D., "Refocusing Electrical Safety, IEEE Transactions On Industry Applications, Vol 42, No 5, 2006.

[34] MÜNGEN, M.U., Türkiye'de İnşaat İş Kazalarının Analizi ve İş Güvenliği Sorunu, Doktora Tezi, İ.T.Ü. Fen Bilimleri Enstitüsü,1993, İstanbul.

[35] DURSUN, S., "İş güvenliği kültürünün çalışanların güvenli davranışları üzerine etkisi”, Sosyal Güvenlik Dergisi, , Cilt 3, Say1 2, 61-75, 2013.

[36] Expert Choice, 2000, Expert Choice 2nd Edition, Expert Choice Inc., Washington, Usa.

[37] ESIN, A., "İş kazalarında değişik yaklaşım; davranışsal güvenlik” Mühendis ve Makina, Cilt 48, Sayı 567 , 3-9, 2007.

[38] MAMATOĞLU, N., "İş kazalarının azaltılmasında davranış temelli iş güvenliği modeli'nin uygulanması" Yayımlanmamış Doktora Tezi, A.Ü.D.T.C.F. Sosyal Bilimler Enstitüsü Psikoloji (Sosyal Psikoloji) Ana Bilim Dalı, 2001. 